\title{
THE INNATE COSMOPOLITAN TRADITION OF INTERNATIONAL LAW
}

\author{
Geoffrey Gordon*
}

\begin{abstract}
This article develops an account of innate cosmopolitanism in international law and relations. Innate cosmopolitanism stands for the proposition that the world as a whole should be considered as an entity relevant in international legal theory, which has interests and a will of its own capable of giving rise to norms of international law. Although innate cosmopolitanism has not been the subject of a dedicated scholarship, in contrast to better known traditions such as liberal cosmopolitanism and cosmopolitan constitutional theory, the concept of innate cosmopolitanism has informed the historical development of international law. Tracing its development from the 16th century Spanish School, this article addresses the scope and substance of the tradition of innate cosmopolitan thought in the discourse of international law; its domain relative to other streams of cosmopolitan thought in international law; and a critical evaluation of the role of innate cosmopolitan ideas in the discourse and development of international law.
\end{abstract}

\section{Keywords}

International law, cosmopolitanism, world phenomenon, sources of law, international legal theory, Spanish school, telos, intersubjectivity

\section{Introduction}

There exists, in international law, a long cosmopolitan tradition that is poorly recognized for what it is. I refer to it as innate cosmopolitanism, to distinguish it from better known streams of cosmopolitan thought, including liberal cosmopolitanism and cosmopolitan constitutional theory in international law and relations. Innate cosmopolitanism stands for the proposition that the world as a whole represents a phenomenon with interests and even a will of its own, and is capable of establishing a foundation for universal norms under international law. Innate cosmopolitanism has never been expressly developed as a doctrine in its own right, and thus lacks the consolidated vocabulary and critical engagement enjoyed by other schools of cosmopolitan thought, such as liberal cosmopolitanism and cosmopolitan constitutional theory. But despite the relative neglect

Thanks to Wouter Werner and Roland Pierik for their help and advice, as well as the organisers of the 2013 CJICL conference.

Copyright $\odot$ the Author(s).

This work is licensed under a Creative Commons Attribution-NonCommercial-NoDerivs 3.0 License. 
of innate cosmopolitan ideas as part of a distinct theoretical construct, the innate cosmopolitan conception, in a variety of terms and contexts, has been central to the narrative and development of modern international law. Moreover, though it has not been developed as part of an express doctrine or school of thought, the innate cosmopolitan idea has been joined to a common historical narrative. This history of the idea, which is consistently taken to find its roots in the Spanish School of the $16^{\text {th }}$ century, has come to function as something like an alternative pedigree, or bona fides, capable of legitimating the innate cosmopolitan appeal to the world as a whole as a discrete source of world norms under international law. This article proposes to observe innate cosmopolitanism as a distinct theoretical construct, and briefly sketches its role in the discourses of modern and contemporary international law over time. In doing so, I aim to address the following: the scope and substance of the tradition of innate cosmopolitan thought in the discourse of international law, including its central concepts, terms and principles; its distinct domain, relative to other streams of cosmopolitan thought in international law; and a critical evaluation of the role of innate cosmopolitan ideas, once recognized, in the discourse and development of international law.

First, it bears noting that international law and international lawyers have regularly been described as cosmopolitan, but the term in this context has remained elusive, or has been taken as self-evident, and is rarely explained with any thoroughness. What does cosmopolitanism generally mean in international law? It does not properly refer to any narrowly orthodox theory or practice of international law, which presumes a consensual system of relations among equal and independent sovereign states. Rather, at its most broad, the cosmopolitan obtains to the cosmopolis: a harmonious and inclusive, universal order. That order stands in opposition to the consensual system, which allows for a cooperative (or uncooperative) anarchy of normative relations. Likewise, when international lawyers are described as cosmopolitan, the association invokes aspirations to a system of law capable of purposefully sustaining order in the world on unified terms. Their cosmopolitan order is an objective one, pretending to a normative authority that is superior to its subjects in principle and defined independently of them. In contrast with the subjective system of international law as it is classically described, cosmopolitanism represents a normative condition that is neither definable nor revocable by state subjects individually, nor by any other subjective actors in their individual capacities. Cosmopolitanism replaces the political authority of sovereign states (and their legacy) with the authority of universal norms.

Cosmopolitan aspirations at law to world order, independent of the political will of states and other subjective interests, have lately received critical atten- 
tion. Scholarship has shed critical light on progressive aspirations to the wouldbe greater good of a unified cosmopolis of world relations, not mediated by subjective attachments. This critical scholarship makes clear that cosmopolitan doctrine, despite its apparent antinomy with orthodox ideas of a consensual system of law among states, is neither wholly oppositional nor exactly subversive in its relationship to international law and international legal discourse. Rather, the cosmopolitan ethos runs like a leitmotif throughout the work of diverse scholars and practitioners in modern international law. Appreciating the cosmopolitan undercurrent of international law-and especially, as I argue here, appreciating the innate cosmopolitan undercurrent of international law-can be crucial to appreciating the historical project of international law, a project that is bound up with the tension between aspirations to objective international norms, and a subjective international system. The critical attention to cosmopolitanism generally, however, has not adequately distinguished among distinct cosmopolitan doctrines, methods and norms, and has not brought out the special role and tradition of innate cosmopolitan ideas in the discourse of international law.

\section{Distinguishing innate cosmopolitanism from other cosmopolitan schools of thought}

Liberal cosmopolitanism is the dominant theory of cosmopolitanism in political theory, and it is regularly applied to international law for purposes of critique or innovation. Moreover, it is a well-developed ethical doctrine in political theory, lately represented by figures such as Simon Caney, Kok-Chor Tan, Allen Buchanan and Thomas Pogge, among others, and develops norms out of what are taken to be universally-acceptable moral premises, independent of the powers of states and other actors in the international system. ${ }^{1}$ Liberal cosmopolitanism is expressive of normative individualism, and bound up with the core norms and values of human rights doctrine. Constitutional cosmopolitanism, on the other hand, is more clearly situated in international legal scholarship, and examines the possibility or reality of a world constitution, lately also incorporating basic tenets of liberal cosmopolitanism, including normative individualism. ${ }^{2}$ Constitu-

\footnotetext{
1 S Caney, 'Cosmopolitan Justice and Institutional Design: An Egalitarian Liberal Conception of Global Governance' (2006) 32 Social Theory and Practice 725; K Tan, Justice Without Borders (2004); A Buchanan, Justice, Legitimacy and Self-Determination: Moral Foundations for International Law (2004); T Pogge, 'Cosmopolitanism and Sovereignty' (1992) 103 Ethics 48.

2 See e.g. A Peters, 'The Merits of Global Constitutionalism' (2009) 16 In J Global Legal Studies 397.
} 
tional cosmopolitanism is closely related to international constitutionalism, and accordingly has received increasing attention in international legal scholarship as theories of world constitution have enjoyed renewed interest. Constitutional cosmopolitans differ from liberal cosmopolitans insofar as the former identify world norms with the formal establishment of a global political settlement among actors in the international system, creating a new world order independent of its constitutive parts. Constitutional cosmopolitanism is particularly bound up with the method of international law, as it turns on questions of formal sufficiency derived from positive terms of international law. ${ }^{3}$ Innate cosmopolitanism broadly shares the legal method of constitutional cosmopolitanism, insofar as it seeks to ascertain law from a historical source, rather than moral premises in the first instance, but distinguishes itself by reference to a historical source-the phenomenon that is the world as a whole-which precedes and is not contingent upon its acknowledgment as a matter of positive international law.

Despite differences among liberal, constitutional and innate cosmopolitanism, each seeks to establish some autonomous normative power, an objective normativity for the world as a whole, as against the system of subjective authority identified with the relations of equal and independent states. In aspiring to objective world norms exhibiting autonomous bases of legitimacy, each of the three aspires to world norms superior to international politics. Liberal and innate cosmopolitanism, however, emphasize different aspects of cosmopolitan thought: liberal cosmopolitanism emphasizes individuals in the world; innate cosmopolitanism emphasizes the individuality of the world. Constitutional cosmopolitanism, by contrast, is relatively agnostic as between the two: either cosmopolitan vision, liberal or innate, might yield a constitutional arrangement provided it satisfies a certain formal baseline of constitutional legitimacy.

In terms of discourse, each of the three cosmopolitan streams is differently situated. The differences may be conceived as points along a line: at one end, liberal cosmpolitanism represents, as noted, an ethical discourse applied to law; at the other end, constitutional cosmopolitanism represents a legal discourse largely congruent with traditional terms of international law, however radical its use of those terms. Between the two, innate cosmopolitanism represents a legal discourse that eschews some of the traditional terms of international law. The differences are discernible by reference to the different allowance for ascertaining law and different appreciation of sources exhibited by each cosmopolitan

3 J G van Mulligen, 'Global Constitutionalism and the Objective Purport of the International Legal Order' (2011) 24 Leiden J Int L 277, 278. 
school of thought. Liberal cosmopolitanism ascertains law-or the need for legal change-by a deductive, or special constructivist method, the source of which is identical with the substance of select moral premises. Constitutional cosmopolitanism, on the other hand, adheres by comparison to a typically legal, formal means of law-ascertainment, locating constitutional development in traditionally acknowledged sources of international law. ${ }^{4}$ Innate cosmopolitanism, falling between the two, maintains the posture of legal discourse, but nonetheless goes outside the limits of modern international law. In maintaining the posture of legal discourse, innate cosmopolitanism exhibits a framework for law ascertainment by which law is discerned as a discrete historical product, not according to any fixed substance. In going outside the limits of modern international law, innate cosmopolitanism allows for the ascertainment of legal norms independent of convention and custom, according to a source not otherwise acknowledged in the positive law of the modern international system. That source is the will or interest of the world as a whole, the normative expression of which is entirely independent of its affirmation-or rejection-by any one or several of the subjective constituents (such as states) that it comprises.

Where liberal cosmopolitanism presents a well-articulated ethical theory, and constitutional cosmopolitanism observes more closely the traditional constraints of international law, innate cosmopolitanism is roughly predicated on an intuition that is basically sociological in character: the world as a whole represents a discrete social or political collective capable of exhibiting subjective characteristics, including discrete interests and a will of its own, like other individuals and collectives. Moreover, where liberal cosmopolitanism functions primarily to measure existing institutions against an ethical cosmopolitan standard, and where constitutional cosmopolitanism functions primarily to articulate or identify formal standards by which a cosmopolitan constitution may be recognized, innate cosmopolitanism functions primarily like a heuristic device. Never expressly developed as a discrete doctrine, innate cosmopolitanism has served as an implicit model to guide the development of the international system towards certain normative ends associated with the interests or will or the world as a whole, discerned in roughly sociological and historical terms.

The normative ends of the innate cosmopolitan heuristic model include the purportedly objective ends of an interdependent world, and an affirmation of its interests above and beyond the politics of sovereign states and all other

\footnotetext{
${ }^{4}$ Cf J d'Aspremont, Formalism and the Sources of International Law: A Theory of the Ascertainment of Legal Rules (2011) 77-82.
} 
exercises of subjective interest. Moreover, those ends are taken to be not only desirable, but necessary to make a coherent doctrine out of modern international law: where the cooperative venture that a strictly subjective system represents is perceived as not rising in theory to the level of a binding system of law, ${ }^{5}$ innate cosmopolitanism establishes an objective authority, in the form of the world as a whole, capable of grounding the normativity of international law. In this way, from Vitoria and the beginning of the narrative of modern international law onwards, innate cosmopolitanism addresses a question of what, if anything, makes rules binding among subjective actors who are nominally sovereign. It does so with a perhaps deceptively straightforward argument: the world itself also represents a subjective actor in the sum of its interdependent social conditions.

As the sole all-inclusive subjective actor, the world represents an objective actor vis-à-vis every other subjective actor-every other political collective-within its parameters. This does not necessarily elevate the world normatively above other, smaller political collectives: local and regional attachments may in fact be stronger in terms of immediacy. The global collective, however, does enjoy an exclusive claim to objectivity as against all of those other collectives and particular attachments. Accordingly, the world society represents the primary level of social or political order, though not the most immediate. Local and regional collectives enjoy normative status as part of the public order arising out of a world social phenomenon, and they are all co-constitutive of one another. The co-constitutive relationship arises out of the perception of a common capacity for social interaction, taken to establish the essential condition from which world norms will arise in a situation of global interdependence. Because the essential condition is uniform, certain bedrock norms ordering the proper expression of the common social capacity will inhere across the whole of the interdependent sphere. But while the bedrock norms will be common across the interdependent sphere, social interaction will also give rise to diverse norms across time and space. Norms will vary with historical, material and cultural conditions in the world, while the basic phenomenon of a unified world unit with normative consequences will not. Affirming the proper expression of normative authority enjoyed by the world as a whole becomes a matter of proper observation or discernment.

Where liberal cosmopolitanism affirms the individual and particular, innate cosmopolitanism attempts to redeem the whole. The world itself is the essential unit for normative purposes, an independent sociological phenomenon. The

${ }^{5}$ Cf A Snow, 'The Law of Nations' (1912) 6 AJIL 890, 892. 
method is largely inductive: the world represents a complex but unified social phenomenon exhibiting certain historically contingent but generally applicable norms, which are discoverable with sufficient observation and reflection. The generally applicable norms associated with the world collective may alike be seen to underlie or arise out of the diversity of particular norms in sub-global collectives. In either case, the norms that flow from the innate cosmopolitan model must be discerned by reference to the sum total of normative behavior bearing on interdependence in the world collective. The differences between liberal and innate cosmopolitanism, however, can be deceptive: the individuals that make up the global basis of the liberal cosmopolitan order are treated only according to properties that are held to be universal, or universally-acceptable, across all individuals. The liberal cosmopolitan order is wholly consolidated around one normative source, an individual abstracted, such that all of the world's individuals are consolidated by abstraction into one universal individual. The effect is a narrow normative mandate: the individual serves as the singular normative source for world justice. The top-down model of innate cosmopolitanism, by contrast, purports to recognize normative diversity in the world. The bedrock normative phenomenon is not, or is not supposed to be, an abstraction, and the innate cosmopolitan methodology is neither deductive nor constructivist. Rather, the innate cosmopolitan model purports to draw its normative underpinnings from the observation of the diversity of acts, experiences and expectations expressive of the world phenomenon at any given point in time.

Predicated on the observation and expression of global interests and global will, innate cosmopolitanism vindicates the subjectivity of the world itself. Consider Judge Weeramantry's reading of the UN Charter, in his dissent from the Court's advisory opinion in Legality of the Threat or Use of Nuclear Weapons case:

The Charter's very first words are 'We, the peoples of the United Nations'-thereby showing that all that ensues is the will of the peoples of the world. Their collective will and desire is the very source of the United Nations Charter and that truth should never be permitted to recede from view. In the matter before the Court, the peoples of the world have a vital interest, and global public opinion has an important influence on the development of the principles of public international law. ${ }^{6}$

\footnotetext{
${ }^{6}$ Legality of the Threat or Use of Nuclear Weapons, Advisory Opinion, ICJ Reports 1996 p 226, 441-42 (Judge Weeramantry, diss).
} 
Judge Weeramantry's statement of the Charter regime captures the basic thrust of innate cosmopolitanism: a mandate in the name of world society or community, and a vision of the world with a social and political interest of its own on which new authority will be based and from which it will draw. Moreover, Judge Weeramantry nowhere in his opinion suggests that the Charter rises to the level of a formal constitutional document, though it reflects the related idea of a constituted collective-and here the relative closeness of innate cosmopolitanism and some constitutional cosmopolitan theory is clear. In positing the constituted world collective as capable of normative authority, Judge Weeramantry turns to its vital interests, as well as an expression of public opinion in its name, to discern the norms available to the Court in its treatment of the matter before it. As such, he employs devices typical of innate cosmopolitanism in application. The attribution of interest and will to a world collective represents an extraordinary legal authority where none might otherwise be available, such that international law may be established by reference to the vital interests of the world collective, as well as global public opinion, in addition to other sources. In this manner, his opinion reflects perhaps the central purpose for which the innate cosmopolitan model is invoked: as a means around positive law limitations in international law.

\section{The history, in brief}

As noted, though innate cosmopolitanism has not been recognized as a discrete school of thought even by its adherents, scholars and practitioners referring to innate cosmopolitan ideas tend regularly to invoke a long history of innate cosmopolitan ideas, in each case largely as though for the first time. The vocabulary has never been sufficiently conformed or consolidated, such that the same historical lessons are repeated in various contexts, and scholars and practitioners regularly refer for a variety of purposes and in a variety of ways to a common history. ${ }^{7}$ Furthermore, because the innate cosmopolitan premise of a world social or political collective capable of establishing norms and normative authority is so difficult to establish empirically, the history of innate cosmopolitan ideas plays an unusually significant role in the argument for innate cosmopolitan normativity. The history of the idea, captured and recaptured in repetitious exercises, serves as a pedigree and bona fides where other support is lacking. In sum, the descriptive and normative uses of the history

Cf M Koskenniemi, 'Empire and International Law: The Real Spanish Contribution' (2011) $61 \mathrm{U}$ Toronto LJ 1, 4-5. 
of the idea are conjoined: the descriptive analysis of innate cosmopolitanism's historical role in canonical works founds its normative potential. Consequently, the regular recourse to an intellectual history of innate cosmopolitanism has bound application of the innate cosmopolitan model to the historical narrative of cosmopolitanism in international law more closely than other, better recognized forms of cosmopolitanism.

Below, I review the tradition of the innate cosmopolitan idea, from its canonical historical roots as they have been invoked, through its $20^{\text {th }}$ century revival, into its contemporary articulations. The presentation is highly partial and selective, in the interests of economy. The intent for present purposes is not to identify all or even most innate cosmopolitan thinkers, nor to capture the whole of the innate cosmopolitan idea; rather it is to offer here only a few select examples capable of illustrating main attributes of the innate cosmopolitan idea in the discourse of international law.

\subsection{The Spanish School}

The roots of the historical narrative are identified in the work of the Spanish School of the $16^{\text {th }}$ century, reflecting the role of the innate cosmopolitan idea as an enduring supposition in support of a coherent system of international law. I turn now very briefly, to a small selection of representative works from the Spanish School, still among the works relied on by contemporary writers in invocations of innate cosmopolitan ideas. ${ }^{8}$

Francisco de Vitoria, working at the University of Salamanca in the early $16^{\text {th }}$ century, developed his ideas in a period of radically disintegrating religious and social cohesion among the peoples of Europe, against which lingering normative cohesion was devolved from the Roman Empire and ecclesiastical authority. At the same time, the world was expanding as a function of the exploration and exploitation of the new world, further stretching the viability of norms and bonds that had historically anchored rules of conduct among peoples in the old world. To substantiate normative cohesion in the face of revolutionary social disintegration, coupled with the expansion of the known world, Vitoria posited a normative potential vested in a comprehensive phenomenon of human collectivity, not identified with imperialist authorities, and also distinct from-but inclusive of-new and independent peoples. The comprehensive phenomenon that he perceived enjoyed the 'force of law' sufficient to make its norms 'binding upon nations'

\footnotetext{
8 See e.g. H Koh, 'Why do Nations Obey International Law?' (1996) 106 Yale L J 2599, 2604-07.
} 
and 'capable of conferring rights' and 'creating obligations.' The phenomenon that Vitoria described would represent, by virtue of being comprehensive, an objective foundation for international law, capable of sustaining international rules over increasingly independent peoples, but without subjecting them to imperial control. He supported this objective foundation by positing an interdependent relationship among the peoples of the world to counter the rise of political independence, an interdependent relationship founded neither in imperial nor ecclesiastical community.

The interdependent foundation that Vitoria established encompassed the world as a whole, taking the entirety of the world of people as a discrete collective entity with interests of its own, capable of establishing an independent or autonomous normative potential. The world as a whole represents a comprehensive collective with normative power by virtue of a capacity and inclination for communication that adheres universally, even if only in potentiality, across the whole of humanity. ${ }^{10}$ In keeping with an Aristotelian premise of a natural propensity for communication, Vitoria founds the normative authority behind international law in the idea that "[n]ature has established a bond of relationship between all men."11 Thus there is a distinct, all-inclusive social phenomenon, not to the exclusion of peoples and states, but different from them, more expansive in scope, and not dependent on them.

The world norms, or universal norms that flow from the world phenomenon, are not to the exclusion of local and particular norms: the same capacity and inclination for social interaction that underlies some universal norms of conduct also give rise to the differentiation of local norms. Hence Vitoria's crucial distinction between what was permitted and what was not permitted to Spanish adventurers in the new world: universal norms affirmed a basic allowance for trade, for missionary purposes, and for communication and interaction generally; but beyond the inviolability of those basic allowances on the basis of universal norms, particular norms were not be overthrown, and subjugation of local populations was illegitimate (though ultimately achieved in part on the basis of what was already allowed). ${ }^{12}$

The product is a normative order that is discrete for flowing from the thing itself, namely the human world as a whole, rather than any subjective aspiration to

\footnotetext{
9 F Vitoria, 'De Indis Noviter Inventis', in J B Scott (ed), The Spanish Origin of International Law: Francisco de Vitoria and his Law of Nations (2000), App A, xxxviii.

${ }^{10}$ F Vitoria, 'De Potestate Civili', in Scott, above n 9, App C, lxxiv-lxxv.

${ }^{11}$ Vitoria, above $n 9$.

12 Ibid, App A. Cf A Anghie, Imperialism, Sovereignty and the Making of International Law (2004) 13-31.
} 
control or guide its present or future. Following Vitoria, international normative prescription derives or may derive from the nature and will of the world as a whole, rather than from the subjective positions of the actors who constitute it or would dominate it; thereby world norms reflect an autonomous and objective foundation, rather than any particular, subjective authority:

that international law has not only the force of a pact and agreement among men but also the force of a law; for the world as a whole being in a way one single State, has the power to create laws that are just and fitting for all persons, as are the rules of international law. Consequently, it is clear that they who violate these international rules, whether in peace or in war, commit a mortal sin; moreover, in the gravest matters, such as the inviolability of ambassadors, it is not permissible for one country to refuse to be bound by international law, the latter having been established by the authority of the whole world. ${ }^{13}$

Thus Vitoria envisioned the world vested with its own authority to effect law, dissociated from the subjective position of any individual not speaking for the inclusive whole of the discrete world phenomenon. Thereby he affirmed an objective normative design intrinsic to the world as a whole, above and beyond the subjective normative designs of the separate states: the law of nations takes its authority in the first place 'in behalf of the common good of all.14 On this basis, 'society at large', encompassing the whole world, can do as a matter of law what 'a State can do to its own citizens. ${ }^{\prime 15}$ Once the nature or will of the world as a whole is determined, as identified with at least a majority of humankind, it may enjoy the force of law 'even though the rest of mankind objected thereto.'

Vitoria's juridical foundations for international law were developed by Francisco Suárez and Grotius, among others, after him. Thus Suárez, in the late $16^{\text {th }}$ to the early $17^{\text {th }}$ century, also at Salamanca for a time, writes of 'true law' that has been 'introduced by the usage and general conduct, not of one or another people, but of the whole world'. ${ }^{17}$ Furthermore, he affirms a moral and political

\footnotetext{
${ }^{13}$ Vitoria, above $\mathrm{n} 10$, App C, $\mathrm{xc}$.

${ }^{14}$ Vitoria, above n 9, App A, xxxviii.

${ }^{15}$ F Vitoria, 'De Jure Belli', in Scott, above n 9, App B, lvi.

${ }^{16}$ Vitoria, above n 9, App A, xxxviii.

${ }^{17}$ F Suárez, A Treatise on Laws and God the Lawgiver, Book VII: Of unwritten law which is called custom, in Selections from Three Works, vol. 2 (1995) 459.
} 
unity in the world, or a universal society, which underlies particular societies. His famous passage is worth quoting in its length:

The human race, into howsoever many different peoples and kingdoms it may be divided, always preserves a certain unity, not only as a species, but also a moral and political unity ... enjoined by the natural precept of mutual love and mercy; a precept which applies to all, even to strangers of every nation. Therefore, although a given sovereign state, commonwealth, or kingdom may constitute a perfect community in itself, consisting of its own members, nevertheless, each one of these states is also, in a certain sense, and viewed in relation to the human race, a member of that universal society; for these states when standing alone are never so self-sufficient that they do not require some mutual assistance, association, and intercourse, at times for their own greater welfare and advantage, but at other times because also of some moral necessity or need. This fact is made manifest by actual usage. ${ }^{18}$

Thus, the universal society is a comprehensive political phenomenon founded in human nature. From that political phenomenon flows the normative authority that gives validity and effect to international law. International law represents those rules and principles identified with the nature and interests of humanity, or the world as a whole, distinct from the political authority and interests that remain vested in particular collectives, including sovereign states.

After Suárez, Grotius has been described as the culminating member of the Spanish School. ${ }^{19}$ Like Vitoria and Suárez before him, he subscribed to an idea of a 'society of mankind' that encompasses the world as a whole. ${ }^{20}$ Grotius founded his society of mankind, derived from the world phenomenon observed by Vitoria and Suárez, in both natural and empirical roots. The natural roots lie in a universal capacity for and inclination to sociability and communication among humans: 'This Sociability, which we have now described in general, or this Care of maintaining Society in a Manner conformable to the Light of human Understanding, is the Fountain of Right, properly so called'. ${ }^{21}$ The empirical grounds for affirming the society of mankind lie in a condition of

\footnotetext{
18 Ibid, 348-49.

${ }^{19}$ Scott, above n 9, 3.

${ }^{20}$ H Grotius, Mare Liberum (1609), ch 1, 5, 12.

${ }^{21}$ H Grotius, The Rights of War and Peace, Prolegomena (1625), paras 7-8.
} 
interdependence, which presumes a state of community from which no particular collective can extract itself, and from which condition the need for law arises. ${ }^{22}$

Notably, among the universal rules flowing from the society of mankind is a right of intervention vested in the world collective and actionable against any local or particular collective. Humankind as a whole possesses certain interests, protected as a matter of norm and law, which particular collectives may not transgress. Thus Grotius holds that, in the case of injustice which 'no good Man living can approve of, the Right of human Society shall not be therefore excluded. ${ }^{23}$ Human society is in this way 'subjectivized', enjoying objective interests and rights of its own, capable of prosecution against all other individuated societies. In this way Grotius, concluding the line of Spanish School scholarship, made the world phenomenon relatively concrete, like in nature to the increasingly sophisticated nation states of the early $17^{\text {th }}$ century, and likewise cognizable as a matter of law, though human sociability is the well-spring of the objective rights and interests of the human society, rather than a positive product of political process.

\subsection{James Brown Scott}

Following Grotius, history attests to the rise of individualism in international law and the international system, largely in opposition to the innate cosmopolitan idea. The story began to change immediately prior to the $20^{\text {th }}$ century. One of the publicists especially responsible for the $20^{\text {th }}$ century revitalization of innate cosmopolitan ideas would be James Brown Scott, who did so principally by reference to the Spanish School. Scott promoted republication of Spanish School works, and wrote a number of works celebrating its elevation of the world as a whole as a discrete and foundational ground for world norms and international law. Scott's work, however, was more than mere restatement. His return to the Spanish School exhibited a clear object and purpose, intended to promote a progressive development of international law by selectively emphasizing and interpreting innate cosmopolitan ideas discernible in the classical scholarship. Thus Scott writes that '[Vitoria's] conception of the community of nations, coextensive with humanity and existing as a result of the mere coexistence of States, without a treaty or convention, is the hope of the future. ${ }^{24}$

\footnotetext{
${ }^{22}$ Ibid, paras 23-24.

${ }^{23}$ Ibid, Book II, ch XXV, sec viii, no 2.

${ }^{24}$ Scott, above n 9, 9a.
} 
The following attributes define the innate cosmopolitan character of international law as Scott understands it to be received from the Spanish School: international law is 'binding upon individual, upon State, and upon the international community [and it is] an international law coterminous with the human race'; ${ }^{25}$ likewise, as a matter of international law, "[w] may conceive of ... an international community, which, being the world, would have jurisdiction over the States and their inhabitants' ${ }^{26}$ moreover, in the absence of any clearer expression, the norms of international law may be both discerned and cultivated by appeal to 'the opinions of mankind. ${ }^{27}$

The idea of universal human society as a ground for normative authority, for Scott, is not a mere abstraction. Rather, it represents a real and verifiable phenomenon in the world: 'we are not dealing with the abstract question-if such there be-but with human beings in society. ${ }^{28}$ The world as a whole represents a discrete society with normative potential capable of giving effect to international law, and, in the absence of a world legislature representative of the world as a whole, proper observation of the norms of humans in society will yield applicable and appropriate rules of international law. In sum, the world as a whole is capable of making international law and authorizing punishment of its violation. ${ }^{29}$ Finally, for Scott, international community is 'not a superimposed State', but it is 'coextensive with humanity'; it is 'self-sufficient'; and it possesses an 'inherent right to impose its will. ${ }^{30}$ In the Vitorian system as described by Scott, exemplary of the innate cosmopolitan model, the international community encompasses the world as a whole and enjoys a will and interests of its own, which establishes norms and normativity foundational to international law.

\subsection{Hersch Lauterpacht}

Another significant proponent of the innate cosmopolitan idea, following Scott, was Hersch Lauterpacht, from whom innate cosmopolitanism received perhaps its most compelling expression. Lauterpacht's work, however, goes beyond innate cosmopolitan ideas, and the focus on them here. Moreover, his work and its cosmopolitan aspects have lately been revisited by Martti Koskenniemi,

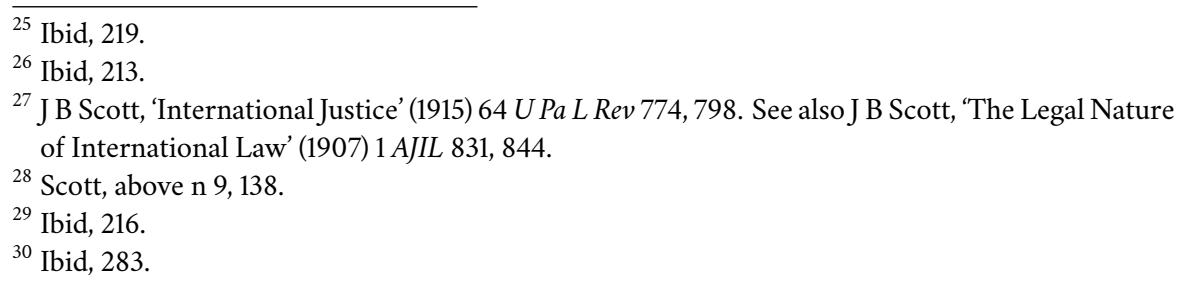


prompting others to do so as well. But cosmopolitanism is a broad term for Koskenniemi. I need here only briefly review aspects of Lauterpacht's work to bring out those specifically expressive of innate cosmopolitan tenets and initiatives. I do so here principally by reference to his reconstruction of the Grotian tradition in international law.

It is clear, first of all, that, for Lauterpacht, Grotius is more than strictly a legal scholar. He is compared with or opposed to Erasmus, Machiavelli, Hobbes and Locke, among others. Grotius's work serves as a model constructed out of political theory, in the way that Lauterpacht makes clear in his earlier treatment of Spinoza, such that the political theory identified with Grotius will help determine the end point of the system that applies to the 'relation of states to humanity.' The legacy of Grotius's political theory and influence in international law is for Lauterpacht 'the tradition of progress and idealism. ${ }^{32}$ Thus Grotius's work comes by the end of the article to represent not only 'a source of evidence of the law as it is, but also as a well-spring of faith in the law as it ought to be. ${ }^{33}$

The sum of the guiding features of the Grotian tradition as Lauterpacht identifies it remains largely synonymous with much of innate cosmopolitanism. Consider the first principle features that Lauterpacht draws out:

They are: the subjection of the totality of international relations to the rule of law; the acceptance of the law of nature as an independent source of international law; the affirmation of the social nature of man as the basis of the law of nature; the recognition of the essential identity of states and individuals; the rejection of 'reason of State'; the distinction between just and unjust war... ${ }^{34}$

The whole of international relations is subject to international law, which is not reducible to state will alone. Rather, the state is placed alongside individuals internationally, and the law of nature-which is an affirmation of the human social character, not derived from a Hobbesian state of nature-is elevated to a source of norms alongside the formal sources of law identified with state consent. $^{35}$

The social unit that defines international law, and in accordance with which international law is defined, is, alternately, international society and international

\footnotetext{
${ }^{31}$ H Lauterpacht, 'Spinoza and International Law' (1927) 8 BYIL 89, 91.

${ }^{32}$ H Lauterpacht, 'The Grotian Tradition in International Law' (1946) 23 BYIL 1, 48.

${ }^{33}$ Ibid, 51 .

${ }^{34}$ Ibid, 51

${ }^{35}$ Ibid, 22-23.
} 
community, as the title of Lauterpacht's most famous work indicates. ${ }^{36}$ International community exhibits 'social and political realities' of its own; international society, its own needs. ${ }^{37}$ By either term, they represent 'the legal and moral unity of mankind. 38 The unity of mankind, again, derives from the social nature of humankind; thus the law of nature that is crucial to Lauterpacht's reading of the Grotian tradition is principally identified with 'the social nature of man and the preservation of human society. ${ }^{39}$ Moreover, it is from the social character of humankind that international law derives the force of its legal norms: 'the binding force of even that part of it that originates in consent is based on the law of nature as expressive of the social nature of man. ${ }^{40}$ In sum:

The place which the law of nature occupies as part of the Grotian tradition is distinguished not only by the fact of its recognition of a source of law different from and, in proper cases, superior to the will of sovereign states. What is equally significant is Grotius's conception of the quality of the law of nature which dominates his jurisprudential system. It is a law of nature largely based on and deduced from the nature of man as a being intrinsically moved by a desire for social life... ${ }^{41}$

What results is a model of a unified legal system that enjoys an objective normative foundation grounded in a world social phenomenon, its norms directed to the proper expression of the universal social character of humankind in an interdependent world.

\subsection{The pretension to observational science and the turn to policy}

The effort to reinvigorate the innate cosmopolitan model in international law was complimented by the contemporaneous perception of a world materially changed by the political and industrial revolutions of the prior epoch. Prior to World War II, jurists focused on renewed doctrine for objective norms, founded

\footnotetext{
${ }^{36}$ H Lauterpacht, The Function of Law in the International Community (2011).

${ }^{37}$ H Lauterpacht, 'The Absence of an International Legislature and the Compulsory Jurisdiction of International Tribunals' (1930) 11 BYIL 134, 151, 153.

${ }^{38}$ Lauterpacht, above n 32, 31.

${ }^{39}$ Ibid, 7.

${ }^{40}$ Ibid, 21.

${ }^{41}$ Ibid, 24.
} 
in a world perceived to have arrived at a stage of appreciable interconnectedness; following World War II, energies were turned to actual research programs necessary to verify the perception of interconnectedness and to substantiate the renewed aspiration to objective normative grounds for international law, as well as conceptual inquiries into the professional and policy implications flowing from potential empirical conditions. Research programs engaged in empirical efforts to discover and promote the empirical grounds of the innate cosmopolitan phenomenon included the World Rule of Law Center at the Duke Law School and the Cornell Project on the Common Core of Legal Systems. I focus here only briefly on yet another project, the Committee for the Study of Mankind, as described by a leading member, Quincy Wright, a political scientist who worked across the fields of international relations and international law. The primary object of the Committee for the Study of Mankind, was 'to make mankind aware of itself and to make this awareness influential at all levels of decision-making. ${ }^{42}$ Self-awareness reflects a singular, 'subjective' psychic capacity associated with the comprehensive human collective. Following the work of the Committee, two objectives are paramount to making mankind aware of itself, namely, world law and world society, which objectives Quincy Wright addressed in the name of the Committee. Law, by Wright's formulation, is essential to communal self-awareness: 'to be aware of itself, mankind-the largest and most complex human group-must have a law. ${ }^{43}$ Society, by the same formulation, is joined to law, though there is a problem of circularity: 'Neither society nor law can exist without the other, but like the hen and the egg, one or the other must come first. ${ }^{44}$ Putting to one side the circularity dilemma, the formula guiding the mission of the Committee held as follows: 'A law of mankind implies that, in some degree, mankind is a society, and this implies that mankind is a public, the members of which, on some matters, have a relatively homogeneous opinion. ${ }^{45}$ Thus, public order for all-inclusive world society-i.e. cosmopolitan order-resolves into the phenomenon of world public opinion. ${ }^{46}$

World public opinion thereby becomes a primary normative foundation for cosmopolitan community: 'Thus it is through the development of a world public opinion, manifesting general understanding and recognition of emerging principles of universal law, that mankind can become aware of itself, of its value,

\footnotetext{
${ }^{42}$ Q Wright, 'Toward a Universal Law for Mankind' (1963) 63 Columbia L Rev 435, 435.

${ }^{43} \mathrm{Ibid}, 437$.

${ }^{44}$ Ibid, 439.

${ }^{45}$ Ibid, 442 .

${ }^{46}$ Ibid, 442 .
} 
and of its intuitions of justice, and can become a functioning society. ${ }^{47}$ The research agenda of the Committee became synonymous with research into the nature of world public opinion: 'The analysis of public opinion may suggest the best approach to conscious control of this process [of the consolidation of human society] and to creation of conditions for a more adequate law of mankind. ${ }^{38}$ Significantly, however, the research agenda can be seen to have shifted from discovery of the nature of the cosmopolitan phenomenon, to the means of directing it. The move to direct the cosmopolitan phenomenon reflects what becomes an increasingly clear connection in innate cosmopolitan scholarship between an inquiry into objective world norms and particular programs of world policy.

Against this backdrop of aspirations, consider the work of the New Haven School, for whom perceived interdependence becomes the grounds for a strong claim: 'It is the fact of an interdependent world community that makes some system of international law inescapable. ${ }^{49}$ The scope of interdependence perceived by members of the New Haven School potentially includes acts and expectations discernible in the interpersonal pursuit of any value, anywhere in the world. The complexity of New Haven School theory, however, takes it beyond the innate cosmopolitan model. I explore it here only for certain points of overlap.

Concerning the range of relevant values, McDougal, Lasswell and Reisman write: 'The increasing interaction and interdependence which have been noted in a few spheres of human activity could easily be demonstrated in regard to the pursuit of every value which human beings covet. ${ }^{50}$ Concerning the involvement of every individual, they write: 'sustained global interaction has rendered the life and stable existence of every individual dependent upon numerous factors operating beyond his local community and national boundaries. ${ }^{51}$ The enormity of the field of interdependence, however, reduces to its effects on individuals, ' $t$ ] he fact which requires emphasis is the highly personal impact of all this interaction and interdependence upon the lives of individual human beings. ${ }^{52}$

By positing such an expansive field of transnational interdependence, the

\footnotetext{
${ }^{47}$ Ibid, 443.

${ }^{48}$ Ibid, 443.

${ }^{49}$ M McDougal, W M Reisman \& A Willard, 'The World Community: A Planetary Social Process' (1987) 21 U Ca Davis L Rev 807, 811.

${ }^{50}$ M McDougal, H Lasswell \& W M Reisman, ‘Theories About International Law: Prologue to a Configurative Jurisprudence' (1967) 8 Va J Int L 188, 191.

${ }^{51}$ Ibid, 190.

${ }^{52}$ Ibid, 191.
} 
New Haven School purports to make good in definitive manner on the comprehensive objective reality that the innate cosmopolitan model represents. The idea of a possible world community is hardened into a world community that exists undeniably in the everyday acts of individuals everywhere: "The inhabitants of the contemporary globe are, unquestionably, the members of a "group," not merely an "aggregate," since they share a sufficiently high frequency of perspectives and interaction. ${ }^{53}$ The global group is synonymous with world community, connoting a relatively thick social order: 'The interdetermination of peoples on a global scale and the pervasiveness of its perception justify the characterization of a "world community". 54

In sum, adherents of the New Haven School 'use the expression "world community" ... not in a metaphoric or wistfully aspirational sense but as a descriptive term. ${ }^{, 55}$ The distinction of the New Haven School from the Vitorian tradition of innate cosmopolitanism is the enhanced proposal to move from intuition and theory to empirical fact, without falling back on the idea of merely-possible community. The naturalist Vitorian reliance on intuition and possibility, though accurate according to the New Haven School as a matter of sensibility, is too subjective to substantiate objective world norms: 'the early "natural" law approach, though sometimes cognizant of the larger community of humankind, more often adopted partial and unevaluated conceptions of that community and did not develop the notion of interpenetrating community processes embracing all peoples. 56

Notably, subjective failure to perceive or appreciate the world community does not diminish its empirical reality. The world community is an objective reality, not contingent on subjective perception, and not merely a possible or theoretical condition to be realized. ${ }^{57}$ In consequence, each individual is, objectively and inescapably, a world citizen: 'Interdependence has made world power processes and world law as relevant to each individual as the decisions made in the municipality in which he lives. Responsible citizenship, then, extends from the municipality to the limits of the enormous arena in which man interacts. ${ }^{, 58}$ Likewise, "[i]n the optimum public order which we recommend, the

\footnotetext{
${ }^{53}$ M McDougal, H Lasswell \& W M Reisman, 'The World Constitutive Process of Authoritative Decision' (1966) 19 J Legal Education 253, 255.

${ }^{54} \mathrm{Ibid}, 256$.

${ }^{55}$ McDougal et al, above n 49, 808-09.

${ }^{56}$ Ibid, 812 .

${ }^{57}$ Ibid, 810 .

${ }^{58}$ McDougal et al, above n 50, 193.
} 
expectations of all individuals equally comprise authority. ${ }^{59}$ In sum, the objective fact of world norms is the sum of subjective acts and expectations in the world interdependent complex, but the subjective actors may be largely unconscious of their contribution to the normative scheme. Consequently, the normative basis shifts between an objective world phenomenon and the countless subjective acts that it comprises. Right policy, then, must be adopted to ensure that the sum or mean of world subjective acts and expectations conform to desirable outcomes, such that the New Haven School tasks itself with 'the invention and evaluation of the alternatives in policy most economically designed to move us through these troubled times of contending systems toward the more complete and perfect world order we seek. 60 The line between inquiry into grounds for world norms, on the one hand, and an exercise in policy-making on the other, is eroded to the point that the complex assertion of interdependence becomes the jumping off point for chosen policy and normative ends.

McDougal expresses the necessity of normative choice anecdotally: 'It may be that ... one may without "disastrous consequences" take coffee from the Arabs and tea from the Chinese, but it does not necessarily follow that one may take cannibalism from the cannibals and remain ... wholly dedicated to the minimal-order principle of no cannibalism. ${ }^{61}$ Moreover, McDougal is clear that the value-goals associated with human dignity, the adopted telos of New Haven School policy, are neither neutral nor transcendent. ${ }^{62}$ Select values associated with human dignity determine the substance and application of international law as a matter of choice and as a matter of observation: 'an international law so conceived will demand that all specific decisions be related to, or grounded in the authority of, the empirical, social-process, secular values of human dignity. ${ }^{\prime 63}$

Thus the New Haven School conjoins innate cosmopolitanism to particular values of human dignity. But the embrace of human dignity by McDougal, if not the whole of the New Haven School, became largely synonymous with western liberal values in general and U.S. foreign policy in particular. ${ }^{64}$ The result being that, as an exercise in world public order proceeding from the world collective,

\footnotetext{
${ }^{59}$ McDougal et al, above n 53, 256 (emphasis original).

${ }^{60}$ M McDougal, 'Perspectives for an International Law of Human Dignity' (1959) 53 Am Soc Int L Proc 107, 116.

61 Ibid, 122.

${ }^{62}$ Ibid, 121.

${ }^{63}$ Ibid, 123.

${ }^{64}$ See e.g. M Koskenniemi, The Gentle Civilizer of Nations: The Rise and Fall of International Law $1870-1960\left(1^{\text {st }}\right.$ edn. 2001), 476.
} 
but embracing select liberal values in particular, the method and policy associated with McDougal took on a liberal hegemonic character. In McDougal's words, ' $\mathrm{t}$ ] he goal of a law of freedom is not the extreme of anarchy, but an ordered, productive, shared liberty and responsibility. ${ }^{36}$ In the words of critics, however, the New Haven School represents 'social engineering' or a cover for US foreign policy. ${ }^{66}$

\subsection{Contemporary theory}

I turn now to two still more current theories of international law, namely, transnational legal process and the interactional theory of international law developed by Jutta Brunnée and Stephen Toope. Both find antecedents or 'analogies' in aspects of the New Haven School. ${ }^{67}$ In addition to an affirmation of the value of process, acts and expectations-or understandings, another term used by Brunnée and Toope-in the formation and identification of international law, both contemporary schools join an appreciation of intersubjective experience to an argument about the normativity of international law. A comprehensive complex of interaction shapes the identity of actors and norms alike, such that world norms may flow from the world itself as a normative unit. Each goes beyond the formal constraints of international law to identify effective world norms with a global intersubjective process; but for both, something particular about the concept or practice of law serves as a constraint on the normative ends at which that process may arrive.

It bears noting, once again, that neither transnational legal process nor interactional theory is wholly synonymous with innate cosmopolitanism. Transnational legal process entertains a rich idea of process that takes it outside of innate cosmopolitanism in certain respects; likewise the constructivist premises of interactional theory correspond with innate cosmopolitan premises but are not identical with them. I explore transnational legal process and interactional theory for the points of overlap with innate cosmopolitanism, but not to offer a comprehensive treatment of either theoretical school on its own terms.

Consider first Harold Koh's work concerning transnational legal process. The world as a whole, according to Koh, is still more thoroughly interdependent

\footnotetext{
${ }^{65}$ McDougal, above n 60, 126.

${ }^{66}$ M Koskenniemi, From Apology to Utopia: The Structure of International Legal Argument (2005), 205-06.

${ }^{67} \mathrm{~J}$ Brunnée \& S Toope, 'International Law and Constructivism: Elements of an Interactional Theory of International Law' (2000) 39 Columbia J Transnat L 19, 25.
} 
than ever, such that he observes a world-wide, transnational phenomenon, characterized by pervasive interaction and consequent intermixing values and interests. Moreover, in keeping with the heuristic application of innate cosmopolitanism, transnational legal process represents a political model by which to comprehend bedrock normative grounds of international law: transnational legal process arises out of and reflects nothing other than the world 'body politic', for which international lawyers, among others, are responsible. ${ }^{68}$ The world body politic, then, features a 'global legal process', which, in itself, is 'normative, and constitutive.6 ${ }^{69}$ Koh describes a process that ties the normativity of international law to the internalization of common norms, as a function of shared engagements in legal fora organized around the interpretation and enunciation of common rules, and capable of shaping the interests and even identities of international actors. $^{70}$

The product is a self-perpetuating world phenomenon, contingent on the continued interaction of actors in the world. Legal process is essential to the phenomenon, insofar as values that Koh holds fundamental to legal practice will constrain the range of normative outcomes to be expected as a matter of interaction and process. ${ }^{71}$ But while the process is normative, it is not determined. The sum total of acts and expectations will dictate appropriate norms at any point in time, subject to the constraints established as a matter of legal process. Actors in the transnational legal process become 'carriers of history' in an international society that is always and necessarily emerging. ${ }^{72}$ International society is the merged product of identities and norms that run in two directions, from the international level to the individual actor and back. The sum total of these multi-directional engagements is a unitary phenomenon with normative consequences; the substance of that phenomenon is not fixed, but can be observed in the totality of the acts and expectations in all of the transnational engagements at any given time. In this way, transnational legal process corresponds with the innate cosmopolitan model.

Interactional theory, in contrast with the lawyerly orientation of transnational legal process, relies largely on the international relations school of constructivism, merged with the legal philosophy of Lon Fuller, to observe a constantly changing, intersubjective complex representing the primary or bedrock

\footnotetext{
${ }^{68}$ H Koh, 'Transnational Legal Process' (1996) 75 Ne L Rev 181, 207.

${ }^{69}$ Koh, above n 8, 2626.

${ }^{70}$ Ibid, 2646.

${ }^{71}$ Koh, above n 68, 184, 206-07.

${ }^{72}$ Koh, above n 8, 2654-55.
} 
normative grounds of international law. Brunnée and Toope rely on constructivism particularly to show "how international law can be an important force in socializing actors and shaping their interests and choices. ${ }^{, 73}$ Actors are socialized into the overarching complex from which international law and relations derive their normative force, and in which actors and structure 'are mutually constituting, and both are inherently social. ${ }^{74}$ Moreover, interactional theory captures a central feature of innate cosmopolitanism from Vitoria forward, namely an appeal to capacity and communication; interactional theory is rooted in 'an assumption about human nature, which is that the main goal of human life is not mere survival, but "maintaining communication with our fellows.", 75 In sum, the world is an intersubjective complex in which actors will be socialized, and which is a consequence of the natural capacity for and inclination towards communication. As a comprehensive intersubjective complex into which all actors are socialized and which is grounded in assumptions of natural fact, the world as a social whole enjoys an objective claim to normative authority.

Following the work of Fuller, Brunnée and Toope anchor the social complex of global community to a common morality, or the 'internal morality' of law, even as international law is made contingent on an 'external morality': 'the internal morality of the law will tend to favor stasis, as upholding settled expectations and predictability, [while] the external morality, rooted in human ends, will appropriately demand change. ${ }^{, 76}$ The intersubjective capacity for common understanding bridges the two: 'the first step in building interactional law is the creation of social legitimacy through the emergence of widely shared understandings. ${ }^{77}$ Notably, however, there appears some ambiguity typical of the innate cosmopolitan model at this point. It is not clear whether the basic criterion of legitimacy, common understanding, arises naturally or must be manufactured: law is either created or it emerges. I return to this point in critique, below.

The moral calculus of interactional legal theory is part of a Fullerian 'vision of the moral community that is a direct challenge to international lawyers and IR theorists. ${ }^{, 7}$ The internal morality of interactional law represents a

\footnotetext{
${ }^{73}$ J Brunnée \& S Toope, 'An Interactional Theory of International Legal Obligation' (2008) No. 08-16 University of Toronto Legal Studies Research Series, 8-9.

${ }^{74}$ Ibid, 9.

${ }^{75}$ Ibid, 19.

${ }^{76}$ Brunnée \& Toope, above n 67, 59.

${ }^{77}$ J Brunnée \& S Toope, 'Interactional International Law: An Introduction' (2011) 3 Int Theory 307, 308.

${ }^{78}$ Brunnée \& Toope, above n 67, 62.
} 
discrete morality appropriate to law, universal in nature, including attributes that law must always and everywhere exhibit to qualify as legitimate and effective. Where transnational legal process observed normative constraints on the world phenomenon arising out of characteristics typical of lawyers and legal practice or legal discourse, interactional theory finds constraints arising out of moral terms identified with law as a theoretical construct.

External morality, on the other hand, reflects historical values associated with a given community. As such, external morality corresponds with the observational premises of innate cosmopolitanism, by which international legal norms must reflect normative acts and expectations discernible in the world community. Brunnée and Toope indicate that 'modest substantive commitments to an external morality evidence an underlying congruence with commonly shared understandings in society. ${ }^{79}$ The tension between internal and external morality reflects a concern about ends: a fixed and universal internal morality is adopted at least to constrain the range of normative possibilities available to international law, since the allowance for and sensitivity to external morality otherwise admits no clear normative distinction or priority as between competing moralities and corresponding normative ends.

It bears emphasizing that interactional theory is not a theory about what international law might be; rather, it is about what international law must be: 'The primary test for the existence of law is not in hierarchy or in sources, but in fidelity to internal values and rhetorical practices and thick acceptances of reasons that make law-and respect for law-possible. ${ }^{80}$ In keeping with the innate cosmopolitan model, interactional theory addresses perceived shortcomings in the traditionally-recognized sources of international law, to allow for the expression of norms arising from the global whole, rather than the volition of sovereign states alone. The appeal to a source of law outside of those captured in Art. 38 of the Statute of the World Court is express:

[I]nternational lawyers can finally eschew the preoccupation with legal pedigree (sources) that has constrained creative thinking within the discipline for generations. Sources of law can be understood as shorthand for shared understandings, the processes of their invocation made legitimate both by strong adherence to an

\footnotetext{
${ }^{79}$ Ibid, 53.

${ }^{80}$ Ibid, 69.
} 
internal morality and by highly circumscribed tests of substantive content. $^{\text {, }}$

In sum, interactional theory, in its development of constructivist insights, reflects the innate cosmopolitan model of a unified world social phenomenon with normative consequences capable of conferring objective grounds for international law, irrespective of traditionally-recognized sources, grounds presupposed to underlie and facilitate interaction across the diverse expressions of community in the world. Moreover, Brunnée and Toope expressly distinguish interactional theory from the other schools of cosmopolitanism considered here at the outset: 'Our theory of legal obligation is not aligned with cosmopolitan liberalism ... or with visions of global constitutionalism. Rather, we envisage interactional law as a particular kind of "community of practice". 82

\section{A critique}

Having traced the contours of the innate cosmopolitan idea, I propose a brief critique formulated along three lines. First, innate cosmopolitanism suppresses political contestation in favor of assertions of observational science or intuition; second, it vests elite actors with an authority for norms even as it situates responsibility for the expression of those norms elsewhere, in the world as a whole as it may be properly observed or intuited; third, it affirms status quo historical conditions by virtue of founding novel normative authority on the nature of the world as it exists at any point in time. Taken together, the three grounds suggest that innate cosmopolitan arguments may ultimately stand, intentionally or not, for policy interests that support the status quo.

In founding a world legal order on the aggregation of observed normative acts and expectations applicable to the world at any given point in time, the rule-making process prefigured by innate cosmopolitanism is emptied of responsibility: the rules appear to create and recreate themselves; they are merely discovered by constant scientific investigation, and announced by the presumptively proper person, body or instrument. Consider the language of Brunnée and Toope, noted above, whereby law 'emerges'. The norm is observed, rather than deliberated or decided upon, or it is derived from world public opinion, or something like it, rather than the reasoned determination of any

\footnotetext{
${ }^{81}$ Ibid, 65.

${ }^{82}$ Brunnée \& Toope, above n 73, 29.
} 
legislator or judge. In light, however, of the vast field contemplated to determine world norms, sociologically or otherwise, at any point in time, the observational method itself reestablishes the contested field of politics in other terms. Any given set of methodological choices by which to comprehend world norms potentially represents a particular policy and discrete set of interests. The complexity of the research apparently necessary to make good on the innate cosmopolitan intuition suggests that it in fact cannot be substantiated or even meaningfully defined. Thus innate cosmopolitanism would suppress subjective international politics by an appeal to science, or sociological observation, but the science or method of observation becomes a new field of contestation, apparently incapable of resolution. ${ }^{83}$

The variability of the innate cosmopolitan phenomenon undermines a guiding purpose to achieving an objective authority for international legal norms, namely, the ability to overcome the paradox and self-contradiction of a subjective system of international law. With variability comes manipulability, and the association of law and policy that also characterizes innate cosmopolitanism takes on a particularly controversial character. Furthermore, the limitations of observational method also expose to critique the underlying premises of an interdependent world collective, revealing a consistent limitation of innate cosmopolitan doctrine since Vitoria: the vision of a world social or political complex remains just that; it is still in the first place a vision or matter of intuition, rather than anything more substantial or precise. In consequence, the appeal to world normativity under innate cosmopolitanism can appear quixotic, or worse: political contestation is suppressed, but responsibility is diminished in an affirmation of unsubstantiated ends.

Moreover, innate cosmopolitanism expressly associates normativity with the perceived historical reality of the world. Because the proper observation of acts, experiences, expectations and understandings in the world is theoretically supposed to yield the interests and will of the world, the normativity of the world is discerned in terms of historical fact. Likewise, since the norms that flow from innate cosmopolitanism are effectively discovered by observation of historical acts and conditions of the world, innate cosmopolitan norms are supposed to represent the world as it is. To represent the world as it is, is to represent the status quo. Thereby the innate cosmopolitan model adopts a posture deeply tied to historical circumstance, likewise binding the norms to which the model would

${ }^{83}$ M Koskenniemi, 'The Fate of Public International Law: Between Technique and Politics' (2007) 70 Modern L Rev 1, 1. 
give rise to status quo historical conditions. As a consequence, the historical contingency of innate cosmopolitan norms suggests, at least in theory, a model that ultimately serves to affirm-even in its application for reform-status quo conditions, despite a traditional association of innate cosmopolitan ideas with progressive legal scholarship. There are at least two implications to be drawn. Either the appeal to historical reality appears specious, in which case the innate cosmopolitan argument is emptied of its own pretension to legitimacy; or there is reason to be skeptical about the capacity of the innate cosmopolitan idea to support the progressive ends for which it is traditionally invoked.

\section{Redeeming the intuition}

The story, however, does not end with the critique. Innate cosmopolitanism purports to offer a compelling account of a world phenomenon, which indeed appears to resonate with an internationally-conscious audience, be it diplomats, scholars, or a world public, loosely defined. The innate cosmopolitan account substantiates the international normative regime in a coherent way: there is a foundational normative potential that lends an authority to international law beyond the subjective authority of its subjects. Likewise, innate cosmopolitanism has indeed enjoyed a long history of appeal, which continues to represent arguably its greatest strength. It has been suggested, in other places and other words, that the persistent historical intuition of innate cosmopolitanism may be its best proof. ${ }^{84}$ In that light, innate cosmopolitanism functions like a sort of lodestar: a guide by which to orient the ends of international law, and thereby a means of affirming the normativity of the international legal system. In this context, even the most trenchant critic will often appear to share the fundamental intuition that drives the innate cosmopolitan model, exhibiting a faith in the ends of international law even absent any more definitive or scientific exposition of the same.

Consider in particular the critical work of Martti Koskenniemi, who has deconstructed cosmopolitanism generally in international law in a number of places. Koskenniemi's critical work first explicates the dilemma of indeterminacy, then identifies a corrective, for purposes of international law, in the form of a sort of presumptive normative compass-which normative compass resembles the intuitive faith exhibited by innate cosmopolitanism.

${ }^{84}$ Cf Salvador de Madariaga, The World's Design (1938), 84. 
In his earlier work, Koskenniemi identifies a normative compass with the imagination; in his later work, it takes on a still more spiritual dimension. He begins from a critique of international law and international lawyers for failing to recognize or acknowledge the inevitability of political contestation, such that the practice and discourse even of progressive and cosmopolitan international law becomes selectively associated with and co-opted by policy agendas. In the first edition of From Apology to Utopia, the imagination is the corrective to the critical dilemma: 'As international lawyers, we have failed to use the imaginative possibilities open to us', and '[n]ormative imagination-reasoned folly-must take over where the technique of legal interpretation left off. ${ }^{85}$ Imagination already suggests the visionary character that marks the long tradition and appeal of innate cosmopolitanism, and continues to represent perhaps its most persuasive attribute. As of The Gentle Civilizer of Nations, just over ten years later, Koskenniemi's language is changed. The universal is no longer exactly or simply redeemed by imagination; in its place, Koskenniemi explains that the universal is neither a fixed principle nor a process but a horizon of possibility that opens up the particular identities in the very process where they make their claims of identity. ${ }^{, 86}$

Finally, by the time of Koskenniemi's 2007 address before the London School of Economics, which address represents one of the two fullest statements of revision to his earlier work and response to criticism it received, ${ }^{87}$ the nature of the normative compass that informs his critical project is further developed and changed. To begin with, the critical project is clearly presented as a project of critical universalism: 'The task for international lawyers is not to learn new managerial vocabularies but to use the language of international law to articulate the politics of critical universalism. ${ }^{88}$ Furthermore, the politics of critical universalism take on an apparently spiritual character. The horizon of possibility is changed to a horizon of transcendence, and what was once a matter of imagination has become a matter of faith. In the same work, Koskenniemi proposes to reconceive international law such that it might finally fulfill a traditional role as a carrier of the regulative idea of universal community. Moreover, that role corresponds with the actual appeal to international law in the world and by the world. International lawyers 'are appealed to' for the purpose of 'soothing anxious souls' and 'to give voice to frustration and outrage'. Thus

\footnotetext{
${ }^{85}$ Koskenniemi, above n 66, 560, 561.

${ }^{86}$ Koskenniemi, above n 64, 506 (emphasis original).

${ }^{87}$ M Koskenniemi, 'The Politics of International Law-20 Years Later' (2009) 20 EJIL 7, 7.

${ }^{88}$ Koskenniemi, above n 83.
} 
international law is comprehended as a 'secular faith' for the world at large, such that international lawyers resemble its priests, capable of 're-establishing hope for the human species. ${ }^{89}$

Taken together, the foregoing terms and propositions appear of a kind with the ideas and language that have marked innate cosmopolitanism in international law from Vitoria forward as part of a project intended to be progressive, as well as transgressive of subjective orthodoxy in the international system. The innate cosmopolitan model, like the critical universalism described by Koskenniemi, would be progressive and transgressive by virtue of providing a normative telos or orientation capable of moving a system of law otherwise subject to the historical vicissitudes of atomized powers and interests. Koskenniemi's reliance on faith and hope, and his eschewal of more traditional terms of legal discourse and practice, represents a familiar resolution into normative intuition, a sense of a normative endpoint, reference point or 'horizon', one that moves with history but cannot be made perfectly clear, and instead must be discerned at least in part as a 'gut feeling.' 90

In conclusion, that even critical legal theory resolves into an intuitive assumption similar to that of innate cosmopolitanism, attests to the enduring appeal of the innate cosmopolitan idea, despite its discontents. If, ultimately, the innate cosmopolitan intuition will not be denied in the discourse of international law, it must be better understood. The terms of its articulation and the ends to which those terms are applied in the discourse of international law call for more consistency, and more consistent recognition. Doing so will allow for a clearer and more comprehensive critical treatment of innate cosmopolitanism as a school of thought-including the method of innate cosmopolitan argumentation, its premises and the ends to which they are put as well as its particular instantiations.

\footnotetext{
${ }^{89}$ Ibid, 30 .

${ }^{90}$ Koskenniemi, above n 87, 18.
} 